\title{
PENGEMBANGAN PENGORGANISASIAN \\ ISI PERKULIAHAN MELALUI MODEL ELABORASI MATA KULIAH \\ PENGEMBANGAN KURIKULUM SD PROGRAM S1 PGSD \\ FKIP UNIVERSITAS KRISTEN SATYA WACANA SALATIGA 2012
}

\author{
Slameto \\ Program Studi S1 PGSD \\ FKIP Universitas Kristen Satya Wacana \\ e-mail:Slameto_uksw@yahoo.com, HP. 081325107010
}

\begin{abstract}
ABSTRAK
Mata Kuliah Pengembangan Kurikulum berfungsi untuk mengantar mahasiswa ke pemikiran yang logis, rasional, kritis, cermat, jujur, efektif dan efisien agar dapat memiliki kemampuan memperoleh, mengolah dan memanfaatkan informasi untuk bertahan, bahkan antisipasi terhadap keadaan yang selalu berubah, dan kompetitif. Isi perkuliahan yang diorganisasi dengan berpijak pada karakteristik isi perkuliahan diharapkan dapat me- ningkat- kan perolehan hasil belajar dan retensi yang lebih baik. Salah satu peng- organisasi- - an isi perkuliahan adalah dengan model elaborasi. Rumusan masalah dalam penelitian ini adalah bagaimanakah pengoraganisasian isi perkuliahan Pengembangan Kurikulum SD dengan model elaborasi untuk meningkatkan belajar mahasiswa menjadi lebih baik atau efektif; dengan demikian tujuan penelitian ini adalah untuk menghasilkan perangkat perkuliahan yang teruji efektif meningkatkan hasil belajar mahasiswa. Langkah pengembangan modelnya mulai dari 1) studi pendahuluan; 2) perencanaan dan pengembangan model; 3) validasi model melalui pengukuran hasil pembelajaran. Indikator keberhasilan dalam penelitian ini adalah dihasilkanya perangkat perkuliahan yang terbukti efektif atas hasil pengembangan pengorganisasian isi perkuliahan melalui model elaborasi mata kuliah pengembangan kurikulum SD. Pengembangan model elaborasi sebagai salah satu alternatif solusi untuk meningkatkan hasil belajar mahasiswa dengan mengorgani- sasi isi perkuliahan terbukti valid, memiliki keefektifan, efisiensi dan daya tarik yang tinggi. Telah dihasilkannya model pengorganisasian isi perkuliahan dengan model elaborasi untuk Mata Kuliah Pengembangan Kurikulum SD yang teruji efektif meningkatkan hasil belajar mahasiswa.
\end{abstract}

Kata Kunci: Model Pengorganisasian materi, elaborasi, efektif dan efisien; kompetensi.

\section{PENDAHULUAN}

Program Studi S1 PGSD UKSW Salatiga diselenggarakan berdasarkan SK Dirjen Dikti No. 3337/D/T/2006 tanggal 1 September 2006. Kompetensi lulusan yang hendak dicapai Program Studi S1 PGSD adalah sosok utuh kompetensi profesional guru SD, terdiri atas empat kemampuan (a) mengenal secara mendalam peserta didik SD yang hendak dilayani, (b) menguasai lima bahan ajar bidang ke-SD-an, (c) mampu melaksanakan pembelajaran yang mendidik (d) mengembangkan kemampuan professional secara berkelanjutan.

Mata kuliah Pengembangan Kurikulum SD bagi mahasiswa Pendidikan Guru Sekolah Dasar merupakan mata kuliah wajib yang perlu ditempuh. Sesuai dengan karakteristik mahasiswa calon (atau yang telah menjadi) guru SD, Pengembangan Kurikulum SD bagi mahasiswa 
PGSD diarahkan untuk menguasai kemampuan: 1) mengidentifikasi prinsip-prinsip pengembangan kurikulum, 2) mengidentifikasi model dan pendekatan pengembangan kurikulum, 3) mengembangkan kurikulum lima mata pelajaran SD/MI sesuai dengan tuntutan situasi zaman dan kebutuhan peserta didik, 4) mengidentifikasi prinsip-prinsip perencanaan pembelajaran yang mendidik, 5) menyusun rancangan pembelajaran yang mempertimbangkan karakteristik peserta didik dan mata pelajaran untuk mencapai tujuan utuh pendidikan, serta 6) mengembangkan rencana pembelajaran (RPP) untuk praktik mengajar di berbagai tingkatan kelas SD/MI.

Mata kuliah Pengembangan Kurikulum SD merupakan di samping ilmu pengetahuan mendasar yang mesti dikuasai mahasiswa, juga berfungsi untuk mengantar mereka ke pemikiran yang logis, rasional, kritis, cermat, jujur, efektif dan efisien. Kompetensi tersebut diperlukan agar mahasiswa dapat memiliki kemampuan memperoleh, mengolah dan memanfaatkan informasi untuk bertahan bahkan antisipasi terhadap keadaan yang selalu berubah, tidak pasti dan kompetitif. Dengan perkuliahan Pengembangan Kurikulum SD diharapkan peserta didik dapat mengembangkan kemampuan dalam pemecah-an masalah dan mengkomunikasikan ide atau gagasan dengan menggunakan simbol, tabel, diagram dan media lainnya baik secara tertulis maupun secara lisan pada saat ujian akhir.

Mata kuliah Pengembangan Kurikulum SD di satu pihak sebagai ilmu memiliki objek kajian abstrak dan tersusun secara hirarkis, namun juga sebagai ilmu tentang metode (metodologi pengembangan) yang perlu dikuasai bukan hanya secara kognitif saja, tetapi perlu diterapkan dalam pengkajian dan desain kurikulum pada tataran operasional yaitu silabus, RPP dan bahan ajar dan melaporkan hasilnya secara ilmiah. Hal inilah yang merupakan salah satu penyebab sulitnya seorang dosen mengampu mata kuliah Pengembangan Kurikulum SD ini. Seorang dosen pengampu mata kuliah Pengembangan Kurikulum SD harus berusaha mengurangi bahkan menghilangkan sifat abstrak dari objek kajian
Pengembangan Kurikulum SD untuk memudahkan mahasiswa menangkap atau memahami dan menerapkan dalam desain serta penulisan hasilnya. Karena alasan inilah banyak mahasiswa merasa sulit mengikuti kuliah Pengembangan Kurikulum SD; mereka merasa bahwa mata kuliah Pengembangan Kurikulum SD itu sulit, tidak menarik, dan membosankan. Anggapan inilah yang dapat melemahkan semangat belajar mahasiswa sehingga mereka menjadi acuh tak acuh dan juga menyebabkan hasil belajarnya rendah. Dalam perkuliahan Pengembangan Kurikulum SD terdapat beberapa keluhan mahasiswa maupun dari dosen; keluhan menjadi lebih runyam mana kala dosen pengampu sulit menghubungkan materi dengan karakter dan kesiapan mahasiswa, lambat memberi balikan dan sulit dipahami apa maunya dan lain-lainnya.

Secara umum keberhasilan perkuliahan bergantung pada variabel-variabel penting yang diklasifikasikan oleh Reigeluth dan Merril (Degeng, 2005: 11) menjadi tiga hal yaitu: 1) kondisi perkuliahan (instructional conditions), 2) strategi perkuliahan (instructional strategy), dan 3) hasil pembelajaran (instructional outcomes). Jadi, seorang dosen dituntut keprofesionalannya untuk menyiapkan dan mengolah proses perkuliahan yang sesuai dengan tujuan yang ingin dicapai pada kurikulum terlebih kuliah Pengembangan Kurikulum SD.

Menurut Rownstree (Hermaini, B. Pribadi, B.A. dan Surtiani, A. 2010) dalam pengembangan bahan ajar perlu mempertimbangkan 12 prinsip berikut: 1) struktur yang baik, 2) tujuan perkuliahan yang jelas, 3) tersusun dalam unit-unit pembelajaran yang kecil, 4) melibatkan mahasiswa dalam pembelajaran, 5) lengkap, 6) memiliki pengulang-an, 7) memungkinkan mahasiswa melakukan sintesis terhadap materi, 8) mendorong terjadinya proses belajar, 9) bervariasi dalam penyampaian, 10) memungkinkan mahasiswa melakukan adaptasi, 11) memiliki umpan balik, dan 12) memiliki evaluasi yang kontinyu.

Salah satu pengorganisasian isi perkuliahan (Degeng, 1997: 6) adalah dengan model elaborasi, model ini dimulai dengan memberikan kerangka 
isi perkuliahan, kemudian memilih isi bidang studi menjadi bagian-bagian, merincikan tiap bagian, memilah bagian menjadi sub-sub bagian, kemudian merincikan tiap-tiap bagian, begitu seterusnya sampai tingkat kerincian yang dispesifikasi oleh tujuan. Dengan cara seperti ini, maka mahasiswa akan selalu mengaitkan antara tiaptiap sub bagian ke bagian, dan tiap bagian ke konteks yang lebih luas, hal ini tentu menghasilkan retensi yang lebih baik sehingga perolehan hasil belajarnya juga akan meningkat.

Melalui pengorganisasian isi perkuliahan dengan model elaborasi akan meningkatkan kualitas dan hasil pembelajaran, karena melalui urutan, prasyarat, rangkuman, pensintesis, analogi, pengaktifan strategi kognitif, dan kontrol belajar, mahasiswa diharapkan mampu membuat retensi yang lebih baik atas apa yang telah dipelajarinya. Menurut hasil penelitian Degeng (1997: 6) bahwa isi perkuliahan yang diorganisasi dengan berpijak pada karakteristik isi perkuliahan dapat meningkatkan perolehan hasil belajar dan retensi yang lebih baik.

Strategi pengorganisasian isi perkuliahan disebut oleh Reigeluth, Bunderson, dan Merril (Degeng, 2005: 83) sebagai structural strategy, yang mengacu kepada cara untuk membuat urutan (sequencing) dan mensintetis (synthe-sizing) fakta, konsep, prosedur, dan prinsip yang berkaitan. Sequencing mengacu kepada pembuatan urutan penyajian isi bidang studi, dan synthesizing mengacu kepada upaya untuk menunjukkan kepada mahasiswa keterkaitan antara fakta, konsep, prosedur, atau prinsip yang terkandung dalam suatu bidang studi.

Pengorganisasian perkuliahan, secara khusus merupakan fase yang amat penting dalam rancangan perkuliahan. Menurut Ausebel (Degeng, 2005: 84) synthesizing akan membuat topik-topik dalam suatu bidang studi menjadi lebih bermakna bagi si-belajar, yaitu dengan menunjukkan bagaimana topik-topik itu terkait dengan keseluruhan isi bidang studi. Sedangkan menurut Gagne (Degeng, 2005: 84) sequencing atau penataan urutan juga penting, karena amat diperlukan dalam pembuatan sintesis. Sintesis yang efektif hanya dapat dibuat apabila isi telah ditata dengan cara tertentu, dan yang lebih penting, karena pada hakekatnya, semua isi bidang studi memiliki prasyarat belajar.

Penggarapan isi perkuliahan tidak dapat dipisahkan dari karakteristik struktur isi mata kuliah. Ini disebabkan karena isi perkuliahan memiliki implikasi yang amat penting bagi pembuatan urutan dan sintesis antara isi suatu mata kuliah. Ia dapat berupa struktur belajar atau hirarki belajar, struktur prosedural, struktur konseptual dan struktur teoritik.

Salah satu solusi yang diaggap mampu untuk mengorganisasikan isi perkuliahan adalah dengan menggunakan model elaborasi, sebagaimana diungkapkan Degeng (1997: 67) bahwa pengajaran menggunakan pengorganisasian isi dengan model elaborasi lebih unggul dibandingkan dengan pengajaran tanpa mengorganisasi isi terlebih dahulu.

Teori Elaborasi pengajaran dikemukakan Reigeluth dan Stein (Degeng, 1997: 25) menggunakan tujuh komponen strategi, yaitu: 1) urutan elaboratif untuk struktur utama pengajaran, 2) urutan prasyarat perkuliahan (di dalam masingmasing subjek pelajaran), 3) summarizer (rangkuman), 4) syintherizer (sintesa), 5) analogi, 6) cognitive strategy activator (pengaktif strategi kognitif), 7) kontrol belajar.

Sebagaimana diungkapkan Degeng (1997: 28) pengembang-pengembang teori pengajaran sesudah Gagne, seperti Rugeluth, Merrill, dan Bunderson memperkenalkan karakteristik lain dari struktur mata pelajaran yang didasarkan pada hubungan-hubungan yang ada antar bagian isi mata pelajaran. Secara umum, struktur isi perkuliahan dapat dideskripsikan atas struktur konseptual, struktur prosedural, dan struktur teoritik.

Prasyarat perkuliahan didefinisikan sebagai struktur yang menunjukkan konsep-konsep yang harus dipelajari sebelum konsep lain bisa dipelajari. Oleh sebab itu, ia menampilkan hubungan prasyarat belajar untuk suatu konsep. Rangkuman merupakan tinjauan kembali (review) terhadap materi yang telah dipelajari untuk mempertahankan retensi. Fungsi rangkuman 
untuk memberikan pernyataan singkat mengenai materi yang telah dipelajari dan contoh-contoh acuan yang mudah diingat untuk setiap konsep. Rang-kuman yang diberikan di akhir suatu perkuliahan dan hanya merangkum materi yang baru dipelajari disebut rangkuman internal (internal summarizer), sedangkan rangkuman semua materi beberapa kali perkuliahan disebut rangkuman eksternal (within set summarizer).

Pensintesis (synthesizer) adalah komponen teori elaborasi yang berfungsi untuk menunjukkan kaitan-kaitan diantara konsep-konsep. Pensintesis penting karena akan memberikan sejumlah pengetahuan tentang keterkaitan antar-konsep, memudahkan pemahaman, meningkatkan kebermaknaan dengan menunjukkan konteks suatu konsep, memberikan pengaruh motivasional, serta meningkatkan retensi (Degeng, 1997: 29).

Analogi adalah komponen penting dalam perkuliahan karena mempermudah pemahaman dengan cara membandingkan pengetahuan yang baru dengan pengetahuan yang sudah dikenal mahasiswa (Reigeluth dan Stein, 1983). Pemakaiannya lebih efektif apabila disampaikan di awal perkuliah-an (Degeng,1997: 30).

Pengaktifan strategi kognitif adalah keterampilan-keterampilan belajar yang diperlukan mahasiswa untuk mengatur proses-proses internalnya ketika ia belajar, mengingat, dan berpikir yang terdiri atas dua cara: pengadaan melalui perancangan pengajaran dan menyuruh mahasiswa menggunakannya. Penggunaan gambar, diagram, mnemonik, analogi, dan parafrase, serta pertanyaan-pertanyaan penuntun dapat memenuhi maksud ini.

Menurut Merrill(Degeng (1997: 32) konsepsi kontrol belajar mengacu pada kebebasan mahasiswa dalam melakukan pilihan dan pengurutan terhadap isi mata pelajaran yang dipelajari (content control), komponen strategi pengajaran yang digunakan (display control), dan strategi kognitif yang ingin digunakannya (conscious cognition control). Berbagai komponen teori elaborasi di atas, seperti: rangkuman, pensitesis, analogi, memberikan kesempatan kepada mahasiswa untuk melakukan kontrol belajar.
Prinsip-prinsip yang mendasari model elaborasi menurut Degeng (1997: 36) adalah sebagai berikut:

1) Penyajian kerangka isi. Kerangka isi menunjukkan bagian-bagian utama bidang studi dan hubungan-hubungan utama diantara bagian-bagiannya, hendaknya disajikan pada fase pertama perkuliahan.

2) Elaborasi secara bertahap. Bagian-bagian yang tercakup dalam kerangka isi hendaknya dielaborasi secara bertahap.

3) Bagian terpenting disajikan pertama kali. Pada suatu tahap elaborasi, apapun pertimbangan yang dipakai, bagian terpenting hendaknya dielaborasi pertama kali.

4) Cakupan optimal elaborasi. Kedalaman dan keluasaan tiap-tiap elaborasi hendaknya dilakukan secara optimal.

5) Penyajian pensintesis secara bertahap. Pensintesis hendaknya diberikan setelah setiap kali melakukan elaborasi.

6) Penyajian jenis pensintesis. Jenis pensintesis hendaknya disesuaikan dengan isi materi.

7) Tahapan pemberian rangkuman. Rangkuman hendaknya diberikan sebelum setiap kali melakukan pensintesis.

Menyadari hal tersebut, maka perlu dilakukan suatu penelitian ilmiah untuk menemukan sebuah alternatif pemecahan masalah dalam upaya meningkatkan hasil belajar guna meminimumkan mahasiswa yang gagal. Untuk itulah peneliti ingin mengorganisasikan isi perkuliahan Pengembangan Kurikulum SD dengan model elaborasi, hal ini diharapkan mampu memberikan kemudahan dalam perkuliahan lebih tepat dan lebih baik sehingga hasil belajar mahasiswa meningkat.

\section{Rumusan Masalah}

Berdasarkan latar belakang yang telah diuraikan di atas, maka rumusan masalah yang diselidiki dalam penelitian ini adalah "bagaimanakah pengorganisasian isi perkuliahan Pengembangan Kurikulum SD dengan Model Elaborasi untuk meningkatkan belajar mahasiswa menjadi lebih baik atau efektif?" 


\section{Tujuan dan Manfaat Penelitian}

Berdasarkan rumusan masalah yang dikemukakan di atas, maka tujuan penelitian ini adalah untuk menghasilkan model pengorganisasian isi perkuliahan dengan elaborasi yang teruji efektif meningkatkan hasil belajar mata kuliah Pengembangan Kurikulum SD.

Adapun manfaat yang diharapkan dalam penelitian ini adalah:

1. Mahasiswa dapat lebih memahami konsep, prinsip dan prosedur pengembangan dan penilaian kurikulum yang bersifat hirarkis.

2. Penelitian ini juga dapat digunakan dosen dan guru sebagai bahan masukan, khususnya guru $\mathrm{SD}$, untuk meningkatkan kinerja dan profesionalismenya, serta sebagai bahan pertimbangan dalam memilih pengembangan keprofesian (guru/dosen) berkelanjutan.

3. Memberi kontribusi yang berarti bagi PGSD tempat penelitian dalam rangka peningkatan mutu hasil belajar, memberikan kontribusi dalam peningkatan proses perkuliahan baik mata kuliah Pengembangan Kurikulum SD maupun mata kuliah lainnya.

4. Hasil penelitian ini akan memberikan penga laman, wawasan, dan motivasi bagi mahasiswa yang terlibat dalam penelitian sebagai calon pengajar untuk menjalani profesinya nanti.

\section{METODE PENELITIAN}

Metode atau pendekatan yang digunakan dalam penelitian ini adalah penelitian dan pengembangan (research and development), yang terdiri dari tiga langkah yaitu studi pendahuluan, perencanaan dan pengembangan, serta validasi model pembelajaran. Prosedur utama dalam penelitian pengembangan terdiri atas lima langkah yaitu: 1) melakukan analisis produk yang akan dikembangkan, 2) mengembangkan produk awal, 3) validasi ahli, 4) uji coba lapangan, dan 5) revisi produk.

Pengembangan model perkuliahan ini dilakukan melalui tahap studi pendahuluan, perencanaan dan pengembangan, serta validasi model yang didasarkan pada pembelajaran sebagai sistem yang terdiri dari input-proses-output, berkenaan dengan desain, implementasi dan evaluasi serta tindak lanjut pembelajaran.

Desain model perkuliahan yang dikembangkan ini terdiri dari: tujuan, materi dan sumber, prosedur, dan evaluasi pembelajaran (Tyler, 1949). Apabila dibandingkan dengan model pembelajaran efektif, maka model pembelajaran yang dikembangkan ini merupakan proses inkuiri dalam mengatasi masalah perkuliahan mahasiswa sebagai calon guru SD; tidak hanya mengembangkan kemampuan berpikir/kognitif, tetapi juga mengembangkan sikap mahasiswa (openmindedness, respon-sibility, wholeheartedness).

Terdapat 6 langkah/tahapan yang dilalui dalam proses pengorganisasian isi perkuliahan menggunakan model elaborasi menurut Degeng (1997: 46) adalah:

1) Menetapkan tipe struktur orientasi

2) Memilih dan menata ide ke dalam strukturnya

3) Menetapkan isi penting yang akan dimasukkan dalam epitome.

4) Mengidentifikasi dan menetapkan struktur pendukung

5) Menata urutan elaborasi

6) Merancang epitome, tahapan elaborasi, dan pensintesis.

Konteks model elaborasi dalam desain pembelajaran dapat dijelaskan dari langkah-langkah desain pembelajaran yang dikemukakan oleh Degeng (1997). Langkah-langkah tersebut adalah: 1) Analisis Tujuan dan Karakteristik Bidang Studi, 2) Analisis Sumber belajar (kendala), 3) Analisis Karakteristik mahasiswa, 4) Menetapkan tujuan belajar dan isi pembelajaran, 5) Menetapkan strategi pengorganisasian isi pembelajaran, 6) Menetapkan strategi penyampaian isi pembelajaran, 7) Menetapkan strategi pengelolaan pembelajaran, dan 8) Pengembangan prosedur pengukuran hasil pembelajaran. Kedelapan langkah ini dapat dikelompokkan menjadi 3, yaitu:

1) Studi Pendahuluan yang meliputi analisis kondisi pembelajaran mencakup langkah (1), (2), (3), dan (4).

2) Perencanaan dan pengembangan model mencakup langkah (5), (6), dan (7).

3) validasi model termasuk langkah (8) pengukuran hasil pembelajaran. Analisis kondisional 
dilakukan pada langkah-langkah awal, yang selanjutnya dijadikan pijakan dalam mengembangkan model dan strategi pembelajaran.

Instrumen yang digunakan pada penelitian ini adalah lembar observasi dan tes hasil belajar. Lembar Observasi ini terdiri atas dua bagian, yaitu lembar observasi aktivitas dan kemampuan dosen mengelola perkuliahan dan lembar observasi aktivitas mahasiswa. Tes hasil belajar berbentuk tes obyektif dan essay yang dibuat sendiri oleh peneliti sebagai dosen mata kuliah pengembangan kurikulum SD dengan memperhatikan indikator dan tujuan perkuliahan berdasarkan kurikulum yang diterapkan di PGSD. Sebelum digunakan, tes yang telah disusun terlebih dahulu divalidasi oleh validator, dan diujicoba untuk menetapkan tingkat reliabilitas dan validitas, sehingga dapat dikatakan bahwa instrumen ini layak digunakan dalam mengumpulkan data penelitian.

\section{HASIL PENGEMBANGAN DAN PEMBAHASAN}

Pengembangan model perkuliahan Pengembangan Kurikulum SD ini dilakukan melalui tahap: studi pendahuluan, perencanaan dan pengembangan, serta validasi model yang didasarkan pada pembelajaran berkenaan dengan desain, implementasi dan evaluasi serta tindak lanjut pembelajaran. Langkah-langkah desain pembelajaran dalam konteks model elaborasi dalam desain perkuliahan Pengembangan Kurikulum SD dapat dijelaskan seperti berikut ini.

\section{Studi Pendahuluan: Analisis Kondisi Pembelajaran}

\section{Analisis Tujuan dan Karakteristik Mata Kuliah}

Analisis tujuan dan karakteristik isi mata kuliah dilakukan pada tahap awal kegiatan perancangan perkuliahan. Langkah ini dilakukan untuk mengetahui tujuan perkuliahan apa yang diharapkan. Lebih khusus lagi, untuk mengetahui tujuan orientatif pembelajaran: apakah konseptual, prosedural, ataukah teoritik. Demikian pula, untuk mengetahui tujuan pendukung yang memudahkan pencapaian tujuan orientatif tersebut.
Setelah menyelesaikan mata kuliah Pengembangan Kurikulum SD ini mahasiswa mampu mengaplikasikan prinsip-prinsip kurikulum dalam perencanaan dan pengembangan kurikulum SD, baik kurikulum sekolah, kurikulum mata pelajaran, silabus, dan Rencana Pengembangan Pembelajaran.

Tujuan umum perkuliahan mata kuliah pengembangan kurikulum ini selanjutnya dikembangkan menjadi sasaran/target yang lebih spesifik; pada akhir pembelajaran ini mahasiswa diharapkan:

1. Mencapai ketuntasan mata kuliah pengembangan kurikulum di $S D$.

2. Belajar mandiri dengan mengembangkan kreatifitasnya dalam mendalami materi perkuliahan.

3. Memperdalam materi dengan mencari materi pengayaan melalui buku-buku referensi, media internet dan media masa.

4. Mengembangan materi dengan membuat komik, drama, puisi, pantun dan lagu mengenai materi perkuliahan.

5. Memunculkan ide-ide baru yang inovatif dalam mengembangkan kurikulum di SD yang berguna di masa depan.

Analisis karakteristik isi perkuliahan ini dilakukan untuk mengetahui tipe isi materi apa yang akan dipelajari siswa: apakah berupa fakta, konsep, prosedur, ataukah prinsip. Demikian juga, untuk mengetahui bagaimana struktur isi perkuliahan pengembangan kurikulum. Maksudnya, bagaimana struktur orientasi dan struktur pendukung isi mata kuliah yang akan dipelajari mahasiswa.

\section{Analisis Sumber Belajar (Kendala)}

Analisis sumber belajar dilakukan segera setelah langkah analisis tujuan dan karakteristik isi bidang studi. Langkah ini dimaksudkan untuk mengetahui sumber-sumber belajar apa yang tersedia dan dapat digunakan untuk menyampaikan isi pembelajaran. Hasil dari kegiatan ini berupa daftar sumber belajar yang tersedia yang dapat mendukung proses pembelajaran seperti berikut: 
1. Abdullah Idi, 1999. Pengembangan Kurikulum: Teori dan Praktik. Jakarta: Gaya Media Pratama.

2. E. Mulyasa, 2006. Kurikulum Yang Disempurnakan. Bandung: Remaja Rosda-karya.

3. John D. McNeil, 2005. Contemporary Curriculum in Thought and Action, Jossey Bass education,

4. dst.
Menetapkan Tujuan dan Isi Pembelajaran

Langkah keempat adalah menetapkan tujuan belajar dan isi pembelajaran. Langkah ini sebenarnya sudah bisa dilakukan segera setelah melakukan analisis tujuan dan karak-teristik isi mata kuliah.

Hasil dari langkah ini berupa daftar yang memuat rumusan tujuan khusus pembelajaran (juga sering disebut tujuan belajar) dan tipe serta

Tabel 1 Analisis Karakteristik Isi Perkuliahan

\begin{tabular}{|c|c|c|}
\hline Pokok Bahasan & Materi Kuliah & $\begin{array}{l}\text { Tipe Isi } \\
\text { Materi }\end{array}$ \\
\hline 1. Konsep dasar kurikulum & $\begin{array}{ll}\text { 1. } & \text { Pengertian kurikulum; } \\
\text { 2. } & \text { Peran dan fungsi kurikulum; } \\
\text { 3. } & \text { Ciri-ciri dan kedudukan kurikulum; } \\
\text { 4. } & \text { Komponen kurikulum. }\end{array}$ & $\begin{array}{l}\text { Fakta, } \\
\text { Konsep, } \\
\text { Prinsip }\end{array}$ \\
\hline 2. Teori kurikulum & $\begin{array}{l}\text { 1. } \quad \text { Pengertian teori kurikulum. } \\
\text { 2. } \quad \text { Perkembangan teori kurikulum. } \\
\text { 3. } \quad \text { Sub-sub teori kurikulum. } \\
\text { 4. } \\
\text { Berbagai jenis teori kurikulum. }\end{array}$ & $\begin{array}{l}\text { Fakta, } \\
\text { Konsep, } \\
\text { Prosedur, } \\
\text { Prinsip }\end{array}$ \\
\hline $\begin{array}{l}\text { 1. Evaluasi dan rekontruksi } \\
\text { kurikulum }\end{array}$ & $\begin{array}{l}\text { 1. Pengertian evaluasi kurikulum } \\
\text { 2. Ruang lingkup evaluasi kurikulum. } \\
\text { 3. Keterkaitan antara evaluasi kurikulum dengan pengembangan } \\
\text { kurikulum. } \\
\text { 4. Karakter evaluasi kurikulum. } \\
\text { 5. }\end{array}$ & $\begin{array}{l}\text { Fakta, } \\
\text { Konsep, } \\
\text { Prosedur, } \\
\text { Prinsip }\end{array}$ \\
\hline
\end{tabular}

\section{Analisis Karakteristik Mahasiswa}

Langkah berikutnya adalah menganalisis karakteristik si-belajar yaitu mahasiswa peserta kuliah Pengembangan Kurikulum SD. Ini dimaksudkan untuk mengetahui ciri-ciri perseorangan si-belajar. Beberapa yang termasuk di dalamnya adalah bakat, kematangan tingkat berpikir, motivasi, dan kemampuan awalnya. Contoh hasil dari langkah ini seperti berikut.

Mahasiswa peserta kuliah ini adalah angkatan 2009 mereka sudah memasuki tahun ke 3, sudah semester 5; Kemam-puan awal yang diperoleh selama 2 tahun atau 4 semester sudah cukup untuk belajar pada level yang lebih tinggi. Pada umumnya sudah mantap orientasi karirnya untuk menjadi guru SD. Mereka sudah terbiasa berpikir aras tinggi dalam arti aplikasil penerapan, analisis - sintesis dan evaluasi dalam pemecahan masalah. Motivasi belajar termasuk tinggi, semangat kerja dan belajarnya bagus, terbiasa akses internet dan belajar dengan memanfaatkan media dan sumber internet. struktur isi yang akan dipelajari siswa untuk mencapai tujuan belajar yang telah ditetapkan yang selanjutnya dituangkan dalam silabus dan SAP; Daftar yang dikembangkan seperti tertera pada tabel 2.

\section{Perencanaan dan Pengembangan Model Perkuliahan}

Perencanaan perkuliahan

Komponen perencanaan perkuliahan secara umum mencakup empat hal, yaitu: (a) arah dari suatu program perkuliahan yang berupa standar kompetensi mata kuliah, kompetensi dasar, dan indikator-indikatornya, (b) isi atau materi yang harus diberikan untuk mencapai kompetensi tersebut, (c) strategi pelaksanaan, dan (d) penilaian yang digunakan untuk mengukur tingkat keberhasilan pembelajaran. Keempat komponen itu saling terkait satu sama lain.

Prosedur perencanaan pembelajaran diawali dengan pengembangan silabus (kurikulum operasional) dilanjutkan dengan penyusunan rencana 
satuan acara perkuliahan. Silabus pada dasarnya merupakan program yang bersifat makro yang harus dijabarkan lagi ke dalam program-program pembelajaran yang lebih terperinci. Silabus merupakan program yang dilaksanakan untuk jangka waktu yang cukup panjang dan menjadi acuan dalam mengembangkan satuan acara perkuliahan (program untuk jangka waktu yang lebih singkat).

Tabel 2 Menetapkan Tujuan dan Isi Pembelajaran

\begin{tabular}{|c|c|c|c|}
\hline Pokok Bahasan & Isi/Materi Kuliah & $\begin{array}{l}\text { Tipe Isi/ } \\
\text { Materi }\end{array}$ & Tujuan Perkuliahan dan targetnya \\
\hline $\begin{array}{l}\text { 1. Konsep dasar } \\
\text { kurikulum }\end{array}$ & $\begin{array}{l}\text { 1. Pengertian kurikulum; } \\
\text { 2. Peran dan fungsi kurikulum; } \\
\text { 3. Ciri-ciri dan kedudukan kurikulum; } \\
\text { 4. Komponen kurikulum. }\end{array}$ & $\begin{array}{l}\text { Fakta, } \\
\text { Konsep, } \\
\text { Prinsip }\end{array}$ & $\begin{array}{l}\text { 1. Menjelaskan pengertian kurikulum. } \\
\text { 2. Mengidentifikasi peran dan fungsi kurikulum. } \\
\text { 3. Menyebutkan ciri-ciri dan kedudukan kurikulum. } \\
\text { 4. Menunjukkan komponen kurikulum. } \\
\text { 5. Merangkum keseluruhan materi konsep dasar kurikulum. } \\
\text { 6. Menghasilkan kamus dari materi konsep dasar kurikulum. } \\
\text { 7. Menghasilkan materi konsep dasar kurikulum ke dalam } \\
\text { bentuk komik, lagu, puisi, atau drama }\end{array}$ \\
\hline $\begin{array}{l}\text { 2. Teori } \\
\text { kurikulum }\end{array}$ & $\begin{array}{l}\text { 1. Pengertian teori kurikulum. } \\
\text { 2. Perkembangan teori kurikulum. } \\
\text { 3. Sub-sub teori kurikulum. } \\
\text { 4. Berbagai jenis teori kurikulum. }\end{array}$ & $\begin{array}{l}\text { Fakta, } \\
\text { Konsep, } \\
\text { Prosedur, } \\
\text { Prinsip }\end{array}$ & $\begin{array}{l}\text { 1. Menjelaskan pengertian teori kurikulum. } \\
\text { 2. Menjelaskan perkembangan teori kurikulum. } \\
\text { 3. Menunjukkan sub-sub teori kurikulum. } \\
\text { 4. Mengkategorikan jenis teori kurikulum. } \\
\text { 5. Merangkum keseluruhan materi teori kurikulum. } \\
\text { 6. Menghasilkan kamus dari materi teori kurikulum. } \\
\text { 7. Menghasilkan materi teori kurikulum ke dalam bentuk } \\
\text { komik, lagu, puisi, atau drama. }\end{array}$ \\
\hline
\end{tabular}

Tabel 3 Silabus Mata Kuliah Pengembangan Kurikulum SD

\begin{tabular}{|c|c|c|c|c|c|}
\hline No. & $\begin{array}{l}\text { Kompetensi dan } \\
\text { Pengalaman Belajar }\end{array}$ & Materi dan Rinciannya & Kegiatan Pembelajaran & Asesmen & $\begin{array}{l}\text { Beban } \\
\text { Mahasiswa } \\
\text { (Menit) }\end{array}$ \\
\hline 1. & $\begin{array}{l}\text { Mengkaji prinsip- } \\
\text { prinsip perencanaan } \\
\text { kurikulum }\end{array}$ & $\begin{array}{l}\text { a. Prinsip dan hakikat } \\
\text { pengembangan kurikulum. } \\
\text { b. Fungsi dan peranan } \\
\text { pengembangan kurikulum. } \\
\text { c. Pendekatan pengembangan } \\
\text { kurikulum. }\end{array}$ & $\begin{array}{l}\text { - } \begin{array}{l}\text { Menganalisis prinsip dan } \\
\text { hakikat pengembangan }\end{array} \\
\text { kurikulum. } \\
\text { Menganalisis fungsi dan } \\
\text { peranan pengembangan } \\
\text { kurikulum } \\
\text { - Menganalisis pendekatan } \\
\text { pengembangan kurikulum }\end{array}$ & - Tes tertulis & 120 menit \\
\hline 2. & $\begin{array}{l}\text { Berlatih } \\
\text { mengembangkan } \\
\text { kurikulum lima } \\
\text { mata pelajaran } \\
\text { SD/MI sesuai } \\
\text { dengan tuntutan } \\
\text { situasi zaman dan } \\
\text { kebutuhan peserta } \\
\text { didik }\end{array}$ & $\begin{array}{ll}\text { a. } & \text { Organisasi kurikulum. } \\
\text { b. Peranan sekolah dalam } \\
\text { pengembangan kurikulum. } \\
\text { c. Peranan guru dalam } \\
\text { pengembangan kurikulum. } \\
\text { d. Strategi pelaksanaan } \\
\text { kurikulum. } \\
\text { e. Pengembangan kurikulum } \\
\text { sekolah }\end{array}$ & $\begin{array}{l}\text { Membandingkan organisasi } \\
\text { kurikulum tahun berjalan dan } \\
\text { sebelumnya } \\
\text { - Menganalisi peranan sekolah } \\
\text { dalam pengembangan } \\
\text { kurikulum } \\
\text { - Menganalisis peranan guru } \\
\text { dalam pengembangan } \\
\text { kurikulum. } \\
\text { - Berlatih... }\end{array}$ & $\begin{array}{l}\text { - Tes Tulis } \\
\text {-Rancangan } \\
\text { pengembangan } \\
\text { kurikulum } \\
\text { sekolah }\end{array}$ & 120 menit \\
\hline
\end{tabular}

\section{Menetapkan Strategi Pengorganisasian}

Menetapkan strategi pengorganisasian pembelajaran dilakukan setelah analisis dan penetapan tipe serta karakteristik isi pembelajaran. Pemilihan strategi pengorganisasian pembelajaran amat dipengaruhi oleh apa tipe isi bidang studi yang dipelajari dan bagaimana struktur isi itu. Hasil dari langkah ini berupa penetapan model untuk mengorganisasi isi/materi kuliah, baik tingkat mikro maupun makro.

\section{Deskripsi mata kuliah}

Dalam mata kuliah ini akan melakukan beberapa kegiatan perkuliahan yang berkaitan dengan pengembangan kurikulum SD meliputi: Konsep dasar kurikulum, Teori kurikulum, Model dan organisasi pengembangan kurikulum, Landasan pengembangan kurikulum, Pengembangan kurikulum, Perencanaan dan desain pengembangan kurikulum, Implementasi kurikulum dan aplikasinya dalam pembelajaran, Evaluasi kurikulum, KTSP, pengembangan silabus dan RPP, dan Pengembangan bahan ajar. 
Tabel 4 Satuan Acara Perkuliahan (SAP)

\begin{tabular}{|c|c|c|c|c|}
\hline PERT. & KOMPETENSI DASAR & INDIKATOR KOMPETENSI & $\begin{array}{l}\text { METODE/ } \\
\text { STRATEGI }\end{array}$ & RUJUKAN \\
\hline 1 & $\begin{array}{l}\text { Pendahuluan dan } \\
\text { kontrak belajar }\end{array}$ & $\begin{array}{l}\text { Perkenalan, penjelasan silabus, dan } \\
\text { kontrak perkuliahan }\end{array}$ & $\begin{array}{ll} & \text { Interactive } \\
& \text { Lecturing } \\
\mathrm{O} & \text { Brainstorming } \\
\mathrm{O} & \text { Tanya Jawab } \\
\end{array}$ & SAP \\
\hline 2 & $\begin{array}{l}\text { Kurikulum dalam } \\
\text { Pendidikan }\end{array}$ & $\begin{array}{ll}\text { A. } & \begin{array}{l}\text { Pengertian kurikulum dari } \\
\text { beberapa ahli Kurikulum }\end{array} \\
\text { B. } & \text { Konsep Kurikulum } \\
& \text { - Kurikulum sebagai rencana } \\
& \text { - } \quad \text { kelajaran } \\
& \text { Kurikulum sebagai... }\end{array}$ & $\begin{array}{ll}\text { O } & \text { Interactive } \\
& \text { Lecturing } \\
0 & \text { Brainstorming } \\
\mathrm{O} & \text { Tanya Jawab } \\
\mathrm{O} & \text { Resitasi }\end{array}$ & $\begin{array}{l}\text { Oemar Hamalik, Abdullah } \\
\text { Idi, Muhaimin, Toto } \\
\text { Ruhimat, Wina Sanjaya, E. } \\
\text { Mulyasa, dll }\end{array}$ \\
\hline 3 & $\begin{array}{l}\text { Fungsi dan Peran } \\
\text { kurikulum }\end{array}$ & $\begin{array}{ll}\text { A. Fungsi Kurikulum (a-f) } \\
\text { a. fungsi penyesuaian, } \\
\text { b. fungsi integrasi, } \\
\text { B. Peran kurikulum } \\
\text { a. peranan konservatif, } \\
\text { b. peranan kreatif, dan } \\
\text { c. peranan kritis/ evaluative }\end{array}$ & $\begin{array}{ll}\mathrm{O} & \text { Interactive } \\
& \text { Lecturing } \\
\mathrm{O} & \text { Brainstorming } \\
\mathrm{O} & \text { Resitasi }\end{array}$ & $\begin{array}{l}\text { Oemar Hamalik, Abdullah } \\
\text { Idi, Muhaimin, Toto } \\
\text { Ruhimat, Wina Sanjaya, E. } \\
\text { Mulyasa, dll }\end{array}$ \\
\hline & \multicolumn{4}{|c|}{ UTS } \\
\hline 8 & Jenis-jenis Kurikulum & $\begin{array}{ll}\text { A. } & \text { Separated Subject Curriculum } \\
\text { B. } & \text { Correalated Curriculum } \\
\text { C. } & \text { Broad Fiels Curriculum } \\
\text { D. } & \text { Integrated Curriculum }\end{array}$ & $\begin{array}{ll} & \text { Interactive } \\
& \text { Lecturing } \\
0 & \text { Brainstorming } \\
0 & \text { Diskusi kelompok } \\
0 & \text { Tanya Jawab } \\
\mathrm{O} & \text { Resitasi } \\
\end{array}$ & $\begin{array}{l}\text { Oemar Hamalik, Abdullah } \\
\text { Idi, Muhaimin, Toto } \\
\text { Ruhimat, Wina Sanjaya, E. } \\
\text { Mulyasa, dll }\end{array}$ \\
\hline 15 & \multicolumn{4}{|c|}{ Ujian Akhir Semester (UAS) } \\
\hline
\end{tabular}

Sebagai contoh Pokok Bahasan 1 disiapkan

Peta Konsep dan Ringkasan materi serta glosarium seperti berikut ini.

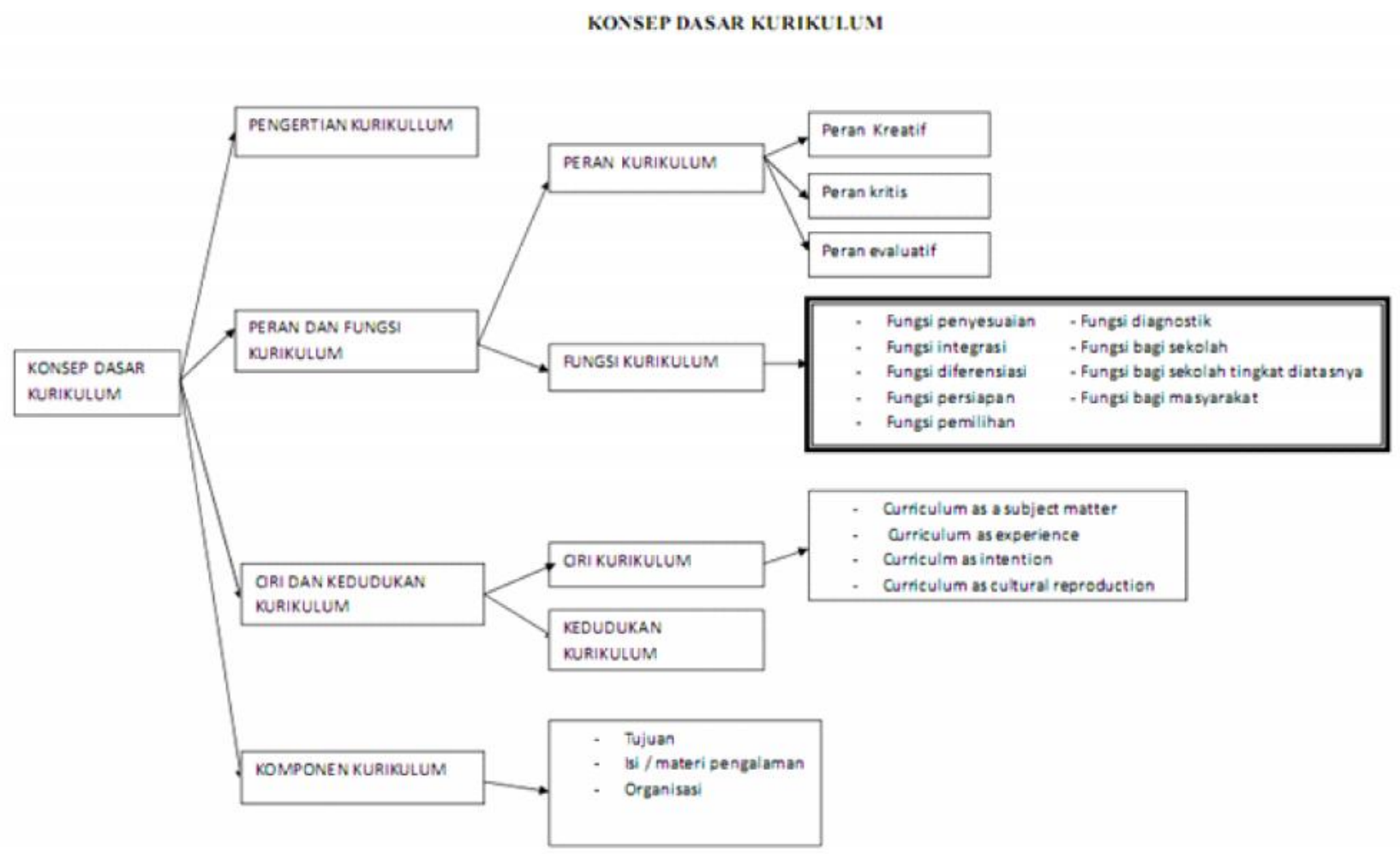




\begin{tabular}{|c|c|}
\hline \multicolumn{2}{|l|}{ Pengertial } \\
\hline \multicolumn{2}{|c|}{$\begin{array}{l}\text { Kurikulum dalam arti sempit yaitu bahan ajar atau } \\
\text { mata pelajaran yang harus disampaikan oleh guru, } \\
\text { sedangkan dalam arti luas kurikulum sebagai } \\
\text { pengalaman. Pengalaman baik bagi siswa, guru, } \\
\text { maupun kepala sekolah, tetapi yang paling penting } \\
\text { pengalaman yang dimaksud berpusat kepada } \\
\text { siswa. Kurikulum dilihat dari segi etimologis... }\end{array}$} \\
\hline $\begin{array}{l}\text { Peranan } 1 \\
\text { 1. Peran K } \\
\text { Peran kc }\end{array}$ & $\begin{array}{l}\text { Kurikulum } \\
\text { Konservatif } \\
\text { xonservatif kurikulum... }\end{array}$ \\
\hline \multicolumn{2}{|c|}{ Fungsi Kurikulum } \\
\hline \multicolumn{2}{|c|}{$\begin{array}{l}\text { 1. Fungsi kurikulum bagi sekolah... } \\
\text { 2. Fungsi kurikulum bagi sekolah... }\end{array}$} \\
\hline \multicolumn{2}{|c|}{ Komponen Kurikulum } \\
\hline \multicolumn{2}{|c|}{$\begin{array}{l}\text { Komponen kurikulum itu terdiri dari: Tujuan } \\
\text { kurikulum, Materi kurikulum, Strategi kurikulum, } \\
\text { Organisasi kurikulum, dan Evaluasi kurikulum. }\end{array}$} \\
\hline \multicolumn{2}{|r|}{ GLOSARIUM } \\
\hline Bahan ajar: & $\begin{array}{l}\text { segala sesuatu yang dapat dipakai atau } \\
\text { diperlukan untuk tujuan tertentu seperti } \\
\text { untuk pedoman atau pegangan, untuk } \\
\text { mengajar. }\end{array}$ \\
\hline $\begin{array}{l}\text { Diferensiasi } \\
\text { Sistem : }\end{array}$ & $\begin{array}{l}\text { si: proses; cara; perbuatan membedakan; } \\
\text { pembedaan; perkembangan tunggal, } \\
\text { kebanyakan dari sederhana ke rumit, dari } \\
\text { homogen ke heterogen. } \\
\text { : perangkat unsur yg secara teratur saling } \\
\text { berkaitan sehingga membentuk suatu } \\
\text { totalitas; susunan yg teratur dari } \\
\text { pandangan; teori; asas; metode. }\end{array}$ \\
\hline
\end{tabular}

\section{Menetapkan Strategi Penyampaian}

Penetapan strategi penyampaian pembelajaran didasarkan pada hasil analisis sumber belajar. Seperti telah dikemukakan sebelumnya bahwa hasil analisis sumber belajar berupa daftar sumber belajar yang tersedia dan dapat digunakan dalam proses pembelajaran, pada langkah ini daftar yang sudah dibuat tersebut dijadikan dasar dalam memilih dan menetapkan strategi penyampaian pembelajaran. Hasil kegiatan dalam langkah ini berupa penetapan model untuk menyampaikan isi pembelajaran. Secara umum, dimulai dengan pendahuluan, dilanjutkan kegiatan inti pembelajaran yang dikelompokkan menjadi dua, yaitu kegiatan inti dalam pembelajaran klasikal, dan kelom-pok. Sebagai contoh untuk pendahuluan atau kegiatan awal pada Pokok Bahasan 8 Evaluasi dan Rekontruksi Kurikulum dilakukan seperti berikut ini.

\section{Pokok bahasan 8: Evaluasi dan Rekontruksi Kurikulum}

Sering kita mendengar istilah evaluasi. Tahukah kamu apa sebenarnya evaluasi itu? Yang kita tahu evaluasi itu seperti alat untuk mengukur keberhasilan seperti kegiatan ulangan maupun tes kecil. Selanjutnya, kamu pasti juga ingin tahu, apa itu evaluasi kurikulum? Banyak para ahli menyumbangkan ide hasil pemikirannya tentang konsep evaluasi kurikulum, antara lain seperti Stephen Wiseman dan Douglas Pidgeson dalam bukunya Curriculum Evaluation. Setiap program yang sudah dilakukan maupun direncanakan, memiliki...Pemahaman yang mendalam akan diperoleh bila membaca uraian dengan cermat, mengerjakan tes formatif mandiri dan mendiskusikannya secara kelompok. Hal yang harus diperhatikan adalah kedisiplinan Anda dalam membaca uraian dan mengerjakan formatif yang terintegrasi dalam uraian akan sangat membantu keberhasilan Anda dalam memahami bahan belajar ini secara keseluruhan. Selamat belajar!

Keberhasilan proses pembelajaran di antaranya dipengaruhi oleh kegiatan pendahuluan (pra dan awal) pembelajaran. Fungsi kegiatan pendahuluan pembelajaran adalah untuk menciptakan awal pembelajaran yang efektif sehingga mahasiswa siap secara penuh dalam mengikuti kegiatan inti pembelajaran.

Kegiatan inti dalam kegiatan pembelajaran klasikal lebih bersifat pemberian informasi dan tanya jawab kelas tentang materi yang dibahas. Pelaksanaan pengembangan kegiatan inti dalam pembelajaran kelompok lebih diarahkan pada kegiatan mahasiswa dalam kelompok untuk menyelesaikan tugas atau masalah. Selain membantu meningkatkan pemahaman mahasiswa terhadap materi perkuliahan, pembelajaran kelompok juga dapat mengembangkan aktivitas sosial serta pengembangan sikap, nilai, dan kerja sama melalui kegiatan pemecahan atau penyelesaian permasalahan dalam kelompok. Sebagai pengantar pada kegiatan awal, untuk pengembangan Pokok Bahasan 9: KTSP dan pengembangan silabus dan RPP disusun seperti tersaji berikut ini. 


\begin{abstract}
Pokok bahasan 9: KTSP dan pengembangan silabus dan RPP

Berdasarkan Undang-Undang Republik Indonesia Nomor 20 Tahun 2003 (UU 20/2003) tentang Sistem Pendidikan Nasional dan Peraturan Pemerintah Republik Indonesia Nomor 19 tahun 2005 (PP 19/ 2005) tentang Standar Nasional Pendidikan mengamanatkan kurikulum...

Pokok bahasan 9 ini akan membahas tentang KTSP, Pengembangan Silabus dan RPP. Supaya kamu dapat memahami materi pokok bahasan 9 ini, bacalah dengan cermat. Pada materi ini menyajikan materi...

Pemahaman yang mendalam akan diperoleh bila membaca uraian dengan cermat, dan mendiskusikan dan melakukan latihan secara kelompok serta mengerjakan tes formatif secara mandiri. Hal yang harus diperhatikan adalah kedisiplinan Anda dalam membaca uraian dan mengerjakan tugas dan tes formatif yang terintegrasi dalam uraian akan sangat membantu keberhasilan Anda dalam memahami bahan belajar ini secara keseluruhan. Selamat bekerja dan belajar!
\end{abstract}

Seusai pengantar atau kegiatan awal, selanjutnya dikembangkan kegiatan inti, dalam model pendekatan kelompok. Sementara itu, kegiatan pembelajaran perseorangan diarahkan untuk mengoptimalkan kemampuan siswa. Kegiatan inti dalam pembelajaran perseorangan menggambarkan kegiatan yang dilakukan oleh setiap individu mahasiswa dalam menyelesaikan tugas yang sudah disimulasikan dalam kelompok.

Kegiatan akhir dan tindak lanjut pembelajaran dilakukan untuk meyakinkan dosen pengampu terhadap penguasaan kompetensi dan keberhasilan proses belajar mahasiswa dalam upaya pemantapan penguasaan kompetensi yang diharapkan. Kegiatan akhir dan tindak lanjut pembelajaran direncanakan dan dilaksanakan secara sistematis, efektif, efisien, dan fleksibel. Selain itu, kegiatan akhir dan tindak lanjut pembelajaran merupakan rangkaian yang utuh dengan kegiatan awal/pendahuluan dan kegiatan inti pembelajaran.

Kegiatan-kegiatan yang dilaksanakan dalam kegiatan akhir pembelajaran adalah sebagai berikut: meninjau kembali penguasaan mahasiswa melalui hasil presentasi atau kesimpulan mahasiswa dan melaksanakan penilaian.
Salah satu contoh instrumen penilaian yang dikembangkan untuk Pokok Bahasan 9: KTSP dan pengembangan silabus dan RPP adalah seperti berikut ini.

\section{Soal Pokok Bahasan 9: KTSP dan Pengembangan Silabus dan RPP}

Saudara, untuk menguji penguasaan kompetensi pada pokok bahasan 9 ini disediakan 2 macam tes yaitu tes Obyektif pilihan ganda dan tes uraian. Jawablah dengan cermat! Waktu yang disediakan untuk mengerjakan tes ini adalah 60 menit.

\section{I.Tes Pilihan Ganda}

1) Para pengembang KTSP dituntut harus memperhatikan ciri khas kedaerahan sesuai dengan ....
a. UU No. 22 Tahun 2000
b. PP No. 19 Tahun 2005
c. UU No. 20 Tahun 2003
d. Permendiknas No. 41 Tahun 20072)

2) Berikut ini yang bukan merupakan karakteristik KTSP yaitu ....
a. berorientasi pada disiplin ilmu
b. berorientasi pada pengembangan individu
c. berorientasi pada kurikulum
d. kurikulum yang mengakses kepentingan daerah

3) Memandirikan dan memberdayakan satuan pendidikan melalui pemberian kewenangan (otonomi) kepada lembaga pendidikan merupakan ...

\section{Tes Uraian}

1) Bagaimana format silabus yang kamu ketahui, buatlah 1 Contoh dari silabus salah 1 Mata Pelajaran Pokok SD?

2) Jelaskan dengan contoh kegiatan yang dilakukan dalam menyusun RPP dengan menuangkan kegiatan elaborasi!

Kegiatan tindak lanjut yang dilakukan dalam pengembangan ini adalah sebagai berikut. Memberikan tugas atau latihan-latihan sesuai kegiatan yang sudah dirancang (untuk Pokok Bahasan 9, menyusun silabus 1 mata pelajaran pokok untuk 1 kelas awal dan 1 untuk kelas atas) dan menjabarkan salah satu KD ke dalam RPP (tematis untuk kelas awal) dan mata pelajaran untuk kelas atas. Selain itu menugaskan membaca materi pokok bahasan dan mengemukakan topik bahasan yang akan datang. 
Menetapkan Strategi Pengelolaan

Menetapkan strategi pengelolaan pembelajaran amat tergantung pada hasil analisis karakteristik si-belajar. Klasifikasi karakteristik si-belajar yang dibuat ketika melakukan analisis karakteristik dijadikan sebagai dasar memilih dan menetapkan strategi pengelolaan. Hasil kegiatan dalam langkah ini berupa penetapan penjadwalan penggunaan komponen strategi pengorganisasian dan penyampaian pembelajaran, pengelolaan motivasional, pembuatan catatan tentang kemajuan belajar siswa, dan kontrol belajar.

Tabel 5 Strategi Pengelolaan

\begin{tabular}{lll}
\hline Waktu & Pokok Bahasan & Kegiatan \\
\hline Pertemuan 2 & $\begin{array}{l}\text { Teori } \\
\text { kurikulum }\end{array}$ & $\begin{array}{l}\text { Presentasi.ceramah, } \\
\text { tanya jawab, } \\
\text { penugasan }\end{array}$ \\
Pertemuan 9 & $\begin{array}{l}\text { Evaluasi } \\
\text { kurikulum }\end{array}$ & $\begin{array}{l}\text { Presentasi/ceramah, } \\
\text { debat,tanya jawab, } \\
\text { penugasan }\end{array}$ \\
\hline
\end{tabular}

\section{Validasi Model: Pengukuran Hasil Pem-} belajaran

Langkah validasi model sebagai langkah terakhir dalam desain perkuliahan Pengembangan Kurikulum SD ini adalah melakukan pengukuran hasil pembelajaran, yang mencakup pengukuran tingkat keefektifan, efisiensi, dan daya tarik pembelajaran. Kegiatan ini dilakukan dengan mengadakan pengamatan proses pembelajaran dan tes hasil belajar. Hasil kegiatan ini berupa bukti mengenai tingkat keefektifan, efisiensi, dan daya tarik perkuliahan.
Validasi model pengembangan perkuliahan ini dipahami jika setelah diterapkan terbukti efektif; Maka dengan melakukan pengukuran hasil belajar ini dipakai sebagai bukti keefektifan perkuliahan. Untuk validasi model ini digunakan dua macam alat ukur yaitu tes dan penilaian kinerja. Tes yang digunakan berupa tes obyektif pilihan ganda dengan 4 alternatif jawaban. Setiap Pokok Bahasan disediakan 10 item soal pilihan ganda dan 2 item soal uraian yang menuntut jawaban luas dan lebih banyak mengukur jenjang kognitif aras tinggi/berpikir. Pengukuran validitas model berikutnya adalah observasi kemampuan dosen sebagai bukti tingkat efisiensi perkuliahan. Validasi model pengembangan perkuliahan ini dipahami jika setelah diterapkan oleh dosen pelaksana/pengembang terbukti efisien berdasarkan penilaian mahasiswanya. Format yang digunakan adalah Lembar Observasi Kemampuan Dosen Mengelola Perkuliahan yang diisi oleh mahasiswa seusai perkuliahan. Hasil pengisian lembar observasi yang dimaksud adalah seperti tertera pada tabel 6 .

Berdasarkan rekap data pada tabel 6 , ternyata 6 dari 15 item kegiatan dosen terfokus (modus) pada aras tinggi, dan 9 dari 15 item kegiatan dosen (40\%) terfokus (modus) pada aras sangat tinggi. Berdasarkan penilaian mahasiswa, setelah diterapkan oleh dosen pelaksana/ pengembang dalam perkuliahan Pengembangan Kurikulum SD, model yang dikembangkan terbukti efisien. Dengan demikian sesuai kriteria efisiensi, model ini dinyatakan valid.

Tabel 6 Lembar Observasi Kemampuan Dosen Mengelola Perkuliahan

\begin{tabular}{lccc}
\multicolumn{1}{c}{ Item Kegiatan Dosen } & Rendah & Sedang & $\begin{array}{c}\text { Tinggi } \\
\begin{array}{l}\text { Dosen menyampaikan semua tujuan } \\
\text { perkuliahan yang ingin dicapai pada } \\
\text { awal perkuliahan. }\end{array}\end{array}$ \\
$\begin{array}{l}\text { Dosen memotivasi mahasiswa untuk } \\
\text { belajar lebih baik. }\end{array}$ & $\mathrm{V}$ \\
$\begin{array}{l}\text { Dosen memfasilitasi mahasiswa } \\
\text { untuk menyajikan hasil kerja di } \\
\text { depan kelas }\end{array}$ & & $\mathrm{V}$ \\
\hline
\end{tabular}


Pengukuran validitas model berikutnya adalah daya tarik mahasiswa terhadap model perkuliahan yang dikembangkan. Observasi aktivitas mahasiswa digunakan sebagai pengukuran daya tarik mahasiswa terhadap model perkuliahan yang dikembangkan. Format yang digunakan adalah Lembar Observasi Aktivitas Mahasiswa yang diisi oleh mahasiswa seusai perkuliahan. Hasil pengisian Lembar observasi yang dimaksud sebagaimana tampak pada tabel 7 berikut ini, belajar mahasiswa dengan mengorganisasi isi perkuliahan terbukti valid.

Pengembangan pengorganisasian materi perkuliahan dengan model elaborasi ini terbukti efisien karena terjadi melalui serangkaian tahapan mulai dari: menetapkan tipe struktur orientasi di mana isi materi perkuliahan dikaji secara cermat agar diketahui tipe struktur orientasinya: apakah konseptual, prosedural, ataukah teoritik. Selanjutnya memilih dan menata ide ke dalam strukturnya, menetapkan isi penting yang akan dimasukkan

Tabel 7 Hasil Pengisian Lembar Observasi Aktivitas Mahasiswa

\begin{tabular}{|c|c|c|c|c|}
\hline Item Kegiatan Mahasiswa & Rendah & Sedang & Tinggi & $\begin{array}{c}\text { Sangat } \\
\text { Tinggi }\end{array}$ \\
\hline $\begin{array}{l}\text { Mahasiswa yang hadir pada proses } \\
\text { perkuliahan memperoleh sesuatu } \\
\text { yang bermakna. }\end{array}$ & & & $\sqrt{ }$ & \\
\hline $\begin{array}{l}\text { Mahasiswa memperhatikan atau } \\
\text { mendengarkan sajian informasi dari } \\
\text { dosen. }\end{array}$ & & & & v \\
\hline $\begin{array}{l}\text { Perkuliahan ini mendukung } \\
\text { peningkatan hasil belajar/prestasi } \\
\text { mahasiswa. }\end{array}$ & & & $\sqrt{ }$ & \\
\hline
\end{tabular}

Berdasarkan rekap data seperti tersaji di atas, ternyata 11 dari 13 item (85\%) kegiatan perkuliahan Pengembangan Kurikulum SD ini terfokus (modus) daya tarik mahasiswa pada aras tinggi, dan 2 dari 13 item (15\%) terfokus (modus) pada atau menunjukkan daya tarik sangat tinggi. Berdasarkan penilaian mahasiswa, setelah diterapkan dalam perkuliahan Pengembangan Kurikulum SD, model yang dikembangkan terbukti memiliki daya tarik yang tinggi dan cenderung sangat tinggi. Dengan demikian sesuai kriteria ketertarikan mahasiswa, model ini mendukung peningkatan hasil belajar/prestasi mahasiswa sehingga dinyatakan valid.

\section{Pembahasan}

Indikator keberhasilan dalam penelitian ini adalah dihasilkanya perangkat perkuliahan yang terbukti efektif atas hasil pengembangan pengorganisasian isi perkuliahan melalui model elaborasi mata kuliah pengembangan kurikulum SD. Pengembangan model elaborasi sebagai salah satu alternatif solusi untuk meningkatkan hasil dalam epitome, mengidentifikasi dan menetapkan struktur pendukung, dan menata urutan elaborasi serta merancang epitome, tahapan elaborasi, dan pensintesis. Berikutnya penahapan elaborasi dikembangkan: mulai dari elaborasi tahap pertama, yang mengelaborasi isi yang ada dalam epitome. Kemudian elaborasi tahap kedua, yang mengelaborasi isi yang ada dalam elaborasi tahap pertama, begitu seterusnya, sampai elaborasi yang paling rinci dan lengkap.

Melalui model pengorganisasian ini membuat isi perkuliahan menjadi bagian-bagian penting, kemudian tersintesiskannya kembali dalam bentuk keterkaitan yang penting, sehingga mahasiswa lebih tertarik untuk memahami keterkaitan materi secara keseluruhan, untuk menimbulkan retensi yang lebih baik yang pada gilirannya waktu yang digunakan lebih singkat dan kualitas hasil belajarnya meningkat.

Pengorganisasian isi perkuliahan melalui model elaborasi Mata Kuliah Pengembangan Kurikulum SD ini ternyata dikembangkan dengan struktur yang baik, tujuan perkuliahannya jelas, 
materi/pokok bahasan tersusun dalam unit-unit yang melakukan adaptasi dengan pelibatan pada aras yang tinggi, sehingga mahasiswa mampu melakukan sintesis terhadap materi, mendorong terjadinya proses belajar yang lebih intensif dan dilengkapi dengan evaluasi yang kontinu beserta umpan balik. Dengan demikian wajar jika mampu meningkatkan prestasi belajar dan efisiensi yang tinggi.

Dalam implementasinya dimulai dengan kegiatan pendahuluan dengan menciptakan sikap dan suasana kelas yang menarik dan demokratis; menimbulkan motivasi dan perhatian mahasiswa, memberi acuan dan membuat kaitan. Pengorganisasian isi perkuliahan melalui model elaborasi Mata Kuliah Pengembangan Kurikulum SD ini setelah dikembangkan, implementasinya dimulai dengan kegiatan pendahuluan dengan menciptakan sikap dan suasana kelas yang menarik dan demokratis; menimbulkan motivasi dan perhatian mahasiswa, memberi acuan dan membuat kaitan.

Kegiatan inti perkuliahan yang bervariasi diarahkan pada proses pembentukan pengalaman belajar dan kemampuan mahasiswa, dengan melibatkan mereka sebanyak mungkin, memberikan kesempatan untuk berbuat langsung, dan memenuhi tuntutan/kebutuhan siswa baik individual maupun kelompok. Kegiatan akhir dan tindak lanjut perkuliahan direncanakan dan dilaksanakan secara sistematis, efektif, efisien, dan fleksibel yang juga merupakan rangkaian yang utuh dengan kegiatan awal/pendahuluan dan kegiatan inti perkuliahan. Kegiatan dosen dalam kegiatan akhir perkuliahan adalah meninjau kembali penguasaan mahasiswa melalui hasil presentasi atau kesimpulan mahasiswa dan atau melaksanakan penilaian. Pada tahap akhir semester dosen melakukan pengukuran terhadap hasil perkuliahan yang mencakup tingkat keefektifan, efisiensi dan daya tarik perkuliahan guna menentukan validitas model.

\section{KESIMPULAN}

Berdasarkan proses dan hasil pengembangan dapatlah disimpulkan sebagai berikut:

1. Telah dihasilkanya model pengorganisasian isi perkuliahan dengan elaborasi Mata Kuliah Pengembangan Kurikulum SD yang teruji efektif sebagai salah satu alternatif solusi untuk meningkatkan hasil belajar mahasiswa.

2. Dengan dihasilkannya seperangkat model perkuliahan ini, mahasiswa dapat lebih memahami konsep, prinsip dan serta mampu mengembangkan kurikulum sesuai prosedur yang baku.

\section{DAFTAR PUSTAKA}

Degeng, I. Nyoman S. 1997. Strategi Pembelajaran (Mengorganisasi Isi dengan Model Elaborasi). Jakarta: IKIP Malang Bekerjasama dengan Biro Penerbitan Ikatan Profesi Teknologi Pendidikan Indonesia.

2005. Teori Pembelajaran I. Malang: Program Pascasarjana Magister Pendi-dikan IPS Universitas Kanjuruhan Malang.

. 2005. Teori Pembelajaran II. Malang: Program Pascasarjana Magister Pendidikan IPS Universitas Kanjuruhan Malang.

Hermaini, B, Pribadi, B.A. dan Surtiani, A. 2010. Evaluasi Bahan Ajar SPJJ Teori belajar dan Pembelajaran Pada Fakultas Keguruan dan Ilmu Pendidikan Universitas Terbuka

Tyler, R.W. 1949. Basic Principles of Curriculum and Instruction. Chicago: The University of Chicago Press. 